\title{
Application control region of human mitochondrial DNA in forensic anthropology
}

\author{
Somayyeh Samehsalari, K.Rajasekhara Reddy \\ Department of Studies in Anthropology, University of Mysore, Manasa Gangothri, Mysore-570006, Karnataka, India. \\ *Corresponding author, Email: salarisonya@yahoo.com
}

(Received 1 May 2018; Accepted 18 June 2018; Published 5 September 2018)

\begin{abstract}
Mitochondrial genome has particular features that make it a valuable forensic marker; first of all it is present in each somatic cell in high numbers. Therefore, it is more resistant to degradation and more stable under unfavorable conditions than nuclear DNA (nDNA) in highly damaged, degraded or very small quantity of the samples. Secondly, the high mutation rate, lack of recombination and the maternal mode of inheritance are features which make the mitochondrial DNA (mtDNA) better choice in situations where nDNA cannot be used for the analysis. Thus, forensic Anthropologists can determine how mitochondrial DNA may be best utilized in skeletal remains or hair shafts, which essentially lack nDNA but contain sufficient amounts of mtDNA. The most extensive mtDNA variations between individuals are found within the Control region or hypervariable regions (HVI, HVII, and HVIII) which allowed individuals to be differentiated and it could provide evidence about the identity of crime victims, especially skeletal remains. In this article we review the feature of mtDNA and its role as a reliable tool in Forensic Anthropology.
\end{abstract}

Key Words: Forensic Anthropology, mitochondrial DNA, Hypervariable regions 


\section{Introduction}

DNA is the genetic blue print of an individual; it is present and identical in every cell of the body. As a result, DNA can be taken from saliva, blood, skin cells, sweat, bone cells and hair root for individual identification (Kobilinsky et al., 2007). The DNA profile is unique for each person and because of this property; it can be utilized in forensic investigations (Lembring, 2013). Since the early 1990s, DNA has become a useful tool in forensic studies and has enabled investigators to identify missing persons, war casualties and individuals involved in mass disaster and criminal case (Sheshanna et al., 2014; Hayat et al., 2016). There are two types of DNA can be used for forensic investigations, either nuclear DNA (nDNA) or mitochondrial DNA (mtDNA). When sufficient amount of DNA is present the sample can be processed by analyzing nDNA, and when the sample size is limited like a small segment of the bone, a tooth, or a shaft of hair mtDNA analysis allows determining the origin of such samples (Ballantyne, 1997; Kobilinsky et al., 2007; Butler, 2011).

\section{Location and structure of human mitochondrial DNA}

DNA is found not only in the cell's nucleus, but also in its cytoplasm, in special energyproducing structures called mitochondria (Lembring, 2013; Sheshanna et al., 2014). Each mitochondrion has several copies of its own genome (mtDNA) and there are several hundred to several thousand mitochondria per cell. The mitochondrial genome is a circular double-stranded molecule of 16,569 base pairs in length and it's creating a light (L) strand and a heavy $(\mathrm{H})$ strand contains a greater number of guanine nucleotides than the "light" or L-strand (Butler, 2011). The genome contains the coding region that code for 37 genes include 13 proteins, 2 ribosomal RNAs (rRNA) and 22 transfer RNAs (tRNA) all of which are involved in the production of energy and it's storage in Adenosine Triphosphate (ATP) (McBride et al., 2006). There is also 1122 bp control region or non coding region that contains the origin of replication for one mtDNA strands, but does not code for any gene products (Ballantyne, 1997). There are three hypervariable regions in the D loop (HVI, HVII, and HVIII); these are important and analyzed to determine human identification 
(Fujita, 1995; Lee et al., 1997; Kouvatsi et al., 2001; Allard et al., 2002; Imaizumi et al., 2002; Maruyama et al., 2003; Ricaut et al., 2004; Koyama et al., 2008; Serin et al., 2016).

\section{Inheritance of human mitochondrial DNA genome}

Mitochondrial DNA is maternally inherited, during fertilization of an ovum, only the sperm head penetrates. The sperm head does contain a few mitochondria, but these are not retained after fertilization and degenerated by ubiquitin, allowing only maternal inheritance (Kouvatsi et al., 2001). Sibling and all maternally related family members will have a similar mtDNA sequence. Because the mitochondrial genome does not undergo recombination, the genome is transmitted from generation to generation unchanged in sequence (Thomson, 1998; Macaulay and Richards, 2006; Kobilinsky et al., 2007; Lincoln and Hughes, 2012).

\section{Heteroplasmy in Mitochondrial DNA}

Heteroplasmy is the presence of more than one mtDNA type in a single individual and at a particular base position in a sequence of bases (Melton, 2004). Heteroplasmy may be observed in several ways: first, individual may have more than one mtDNA type in a single tissue; second, individual may represent one mtDNA type in one tissue and a different type in other tissue; third, Individual may heteroplasmic in one tissue sample and homoplasmic in another tissue sample (Melton, 2004).

There are two types of heteroplasmy: length heteroplasmy and sequence heteroplasmy (Butler, 2011). Length heteroplasmies often occur around the homopolymetric C-stretch in HVI at positions 16184 to 16193 and HVII at positions 303 to 310. Sequence heteroplasmy is typically detected by the presence of two nucleotides in a sequence electropherogram (Kobilinsky et al., 2007).

\section{Control region of mtDNA as a reliable tool in forensic anthropology}

Forensic anthropology is best known as the discipline that applies the scientific knowledge of physical anthropology (and often archaeology) to the collection and analysis of legal evidence. More broadly speaking, it is anthropological knowledge applied to legal issues 
(Palo et al., 2007; Slavec, 2012). Recovery, description, and identification of human skeletal remains are the standard work of forensic anthropologists (Palo et al., 2007; Slavec, 2012; Gomes et al., 2017; Stenton et al., 2017). The condition of the evidence varies greatly, including decomposing, burned, cremated, fragmented, or disarticulated remains (Thompson, 2003). Since the early 1990s, DNA has become an increasingly common means of identification for mass fatality victims. Without DNA technology, more than half of the identified victims would not have been identified (Ballantyne, 1997). The human mtDNA has been proven to be a useful tool for identification crime victim's especially skeletal remains (Holland and Parsons, 1999; Bender et al., 2000; Rudbeck et al., 2005; Torroni et al., 2006; Palo et al., 2007; Adams et al., 2008; Alaeddini et al., 2010; Shinoda, 2010; Köhnemann and Pfeiffer, 2011; Blau et al., 2014; Hayat et al., 2016; Amer et al., 2017; Gomes et al., 2017; Stenton et al., 2017; Calacal et al., 2018; Mendisco et al., 2018). Due to its polymorphic nature, high copy number in each cell, maternal inheritance and it can be analyzed even from small, highly damaged and degraded samples (McBride et al., 2006). In most forensic case, the aim of DNA testing is to differentiate between individuals, therefore, areas of DNA that display the highest levels of difference between individuals are the regions of choice for analysis. Two segments of the Control region in mtDNA are highly polymorphic, these are known as hypervariable regions I, and II (HVI, HVII) and they contain the highest levels of variation within the mtDNA genome. These regions do not contain genes and mutations accumulate with a 10 times higher mutation rate than in the coding region (Pakendorf and Stoneking, 2005; Howell et al., 2007). HVI has a sequence of $342 \mathrm{bp}(16,024-16,365)$ and the second HVII, has a sequence of $268 \mathrm{bp}$ (73340). Occasionally a third portion of the control region, known as HVIII has a sequence of $137 \mathrm{bp}$ and span nucleotide positions 438 to 574 . Additional polymorphic site within HVIII can sometimes help resolve indistinguishable HVI/HVII samples (Stoneking et al., 1991; Bremer et al., 1995; Baasner et al., 1998; Tagliabracci et al., 2001; Bini et al., 2003; Gabriel et al., 2003; Edson et al., 2004; Divne et al., 2005; Lander et al., 2008; Lehocký et al., 2008; Fridman and Gonzalez, 2009; Adachi et al., 2014; Bodner et al., 2015). Over the course of typing mtDNA samples from various populations, researchers have observed that individuals often cluster into haplogroups that can be defined by particular polymorphic 
nucleotides. Mitochondrial DNA haplogroups have now been correlated to HV1/HV2 polymorphisms (Table 1).

Table 1. Human mtDNA haplogroup specific control region mutation motifs

\begin{tabular}{|c|c|c|}
\hline Haplogroup & Control Region Polymorphisms & References \\
\hline A & $\begin{array}{c}16223 \mathrm{~T}, 16290 \mathrm{~T}, 16319 \mathrm{~A} \text { 73G, 152C, 235G, } \\
263 \mathrm{G}, 309.1 \mathrm{C}, 315.1 \mathrm{C}\end{array}$ & Lee et al., 2006 \\
\hline $\mathrm{B}$ & $\begin{array}{l}\text { 16166G ,16183C ,16189C, 16193.1C, 73G } \\
, 131 \mathrm{C}, 183 \mathrm{G}, 263 \mathrm{G}, 309.1 \mathrm{C}, 315.1 \mathrm{C}, 499 \mathrm{~A} \\
\end{array}$ & Lander et al., 2008 \\
\hline $\mathrm{C}$ & $\begin{array}{c}16093 \mathrm{C}, 16129 \mathrm{~A}, 16223 \mathrm{~T}, 73 \mathrm{G}, 249 \mathrm{DEL}, 263 \mathrm{G} \\
\text { 315.1C,489C }\end{array}$ & Maruyama et al., 2013 \\
\hline $\mathrm{D}$ & $\begin{array}{c}\text { 16142T, 16179T, 16223T ,16295T, 16325C } \\
16362 \mathrm{C}, 73 \mathrm{G}, 263 \mathrm{G}, 309.1 \mathrm{C}, 315.1 \mathrm{C}, 489 \mathrm{C} \\
\text {,524.1A, 524.2C }\end{array}$ & Lander et al., 2008 \\
\hline $\mathrm{H}$ & $73 \mathrm{~A}$ & Allard et al., 2002 \\
\hline $\mathrm{K}$ & $16224 \mathrm{C}, 16311 \mathrm{C}$ & Allard et al., 2002 \\
\hline M & $\begin{array}{c}\text { 16223T, 16362C 73G, 152C, 194T, 263G, } \\
\text { 309.1C, 315.1C 489C }\end{array}$ & Maruyama et al., 2013 \\
\hline $\mathrm{P}$ & $\begin{array}{c}\text { 16093C ,16129G, 16176T, 16187C, } 16223 \mathrm{C} \\
\text { 16230A, 16266T, 16270T, 16278C } \\
16311 \mathrm{~T}, 16357 \mathrm{C}, 146 \mathrm{~T}, 195 \mathrm{~T}, 212 \mathrm{C}, 247 \mathrm{G} \\
\end{array}$ & McAllister et al., 2013 \\
\hline $\mathrm{T}$ & $\begin{array}{c}16126 \mathrm{C}, 16189 \mathrm{C}, 16260 \mathrm{~T}, 16294 \mathrm{~T}, 73 \mathrm{G}, 152 \mathrm{C}, 194 \mathrm{~T} \\
263 \mathrm{G}, 315.1 \mathrm{C}\end{array}$ & $\begin{array}{l}\text { Ranasinghe et al., } \\
2015\end{array}$ \\
\hline $\mathrm{U} 4$ & $16356 \mathrm{C}$ & Salas et al., 2000 \\
\hline U5 & $16270 \mathrm{~T}$ & Salas et al., 2000 \\
\hline $\mathrm{V}$ & $16298 \mathrm{C}, 72 \mathrm{C}$ & Allard et al., 2002 \\
\hline $\mathrm{W}$ & 16223T, 189G ,195C, 204C, 207A & Allard et al., 2002 \\
\hline $\mathrm{x}$ & 16189C, 16223T ,16278T, 195C & Allard et al., 2002 \\
\hline Y & $\begin{array}{c}16192 \mathrm{~T}, 16231 \mathrm{C}, 16291 \mathrm{~T}, 73 \mathrm{G}, 263 \mathrm{G} \\
309.1 \mathrm{C}, 315.1 \mathrm{C}\end{array}$ & $\begin{array}{l}\text { Ranasinghe et al., } \\
2015\end{array}$ \\
\hline $\mathrm{Z}$ & $\begin{array}{c}\text { 16185T, 16223T, 16260T, 73G, 152C, 249DEL, } \\
\text { 263G,315.1C,489C }\end{array}$ & Maruyama et al., 2013 \\
\hline
\end{tabular}




\section{Human mitochondrial DNA reference sequence(s)}

It would be very difficult to totally sequence exemplars (known, reference samples) and evidentiary items and then report this total sequence information from beginning to end. To avoid any confusion in the comparison of two specimens, the forensic analyst compares each specimen's mtDNA sequence to a reference sequence, and then describes differences found at specific sites (Kobilinsky et al., 2007). The reference mtDNA, derived primarily from a human placenta, is known as the Anderson sequence (Anderson et al., 1981). The Anderson sequence is also referred to as the Cambridge Reference Sequence (CRS). Today most laboratories use the revised Cambridge sequence (rCRS) as the reference. This revised reference sequence established in1999, has corrected a number of sequence errors in the original 1981 Anderson sequence (Andrews et al., 1999). Each base in the reference sequence is assigned a number from 1 to 16,569 and forensic analysts use these numbers to compare all other specimens (Kobilinsky et al., 2007).

\section{Mitochondrial DNA analysis}

The following is only a brief summary of the methods and considerations involved in a mtDNA analysis. The variants steps of the mtDNA analysis include sample preparation, DNA extraction, polymerase chain reaction (PCR) amplification, quantification of the DNA, automated DNA sequencing and data analysis (Butler, 2011; Sheshanna et al., 2014).

\section{Sample preparation:}

This step involves cleaning the sample, before DNA extraction can begin, the surface of the sample must be treated to remove contaminating (exogenous) DNA. For bone or teeth sample, this can be achieved by physically removing the surface of the sample, treating it with bleach, irradiating it with ultraviolet light, or a combination thereof (Kaestle and Horsburgh, 2002; Loreille et al., 2007; Sheshanna et al., 2014). Hair sample cleaning involves detergent treatment in an ultrasonic water bath (Sheshanna et al., 2014). 


\section{DNA processing:}

The prepared sample is mixed with various organic chemicals that separate the other biological materials, such as protein. The DNA extraction itself consists of three major steps: - Lysis of the cell membrane (breaking cells open to release the DNA), - Precipitation of proteins (breaking proteins by adding a protease and separating DNA from proteins), and - Separation and collection of DNA from the cell debris. This can be achieved by slightly different methods. DNA can be isolated using e.g. chelex-based, silicabased or phenolic extraction procedures (Kaestle and Horsburgh, 2002; Lembring, 2013; Hayat et al., 2016). The DNA extract is then concentrated, and the section of interest is amplified using the polymerase chain (PCR). PCR amplification of mtDNA is usually done with 34 to 38 cycles, protocol for highly degraded DNA specimens even call for 42 cycles (Wilson et al., 1995; Gabriel et al., 2001). The section of mtDNA most frequently targeted is the hypervariable region of mtDNA, this particular region of DNA is chosen because contain a large majority of the polymorphisms and can provide a powerful resource for human identification (Sheshanna et al., 2014). Once amplified, the DNA of interest quantified and sequenced by cycle sequencing with Big Dye Terminator Cycle Sequencing

Kit (Isenberg and Moore, 1999; Kinra, 2006; Amer et al., 2017). The resulting DNA data can be analyzed by special software, differences and similarities between sequences are read based on the set guidelines (Butler, 2011).

\section{Interpretation of Mitochondrial DNA profile:}

Mitochondrial DNA is used both to associate crime scene samples with individuals and to identify human remains. In both cases, the profile generated has to be compared to the Cambridge or Anderson reference sequence. Differences between the questioned sequence and the Cambridge reference sequence can result in an exclusion, an inclusion (an inability to exclude), or an inclusive finding. The Scientific Working Group on DNA Analysis Methods, better known by its acronym of SWGDAM has recommended the following guidelines for analyzing mitochondrial sequence data: (Scientific Working Group on DNA Analysis, 2003). 
- Exclusion: if there are two or more differences in the base sequence of the questioned and known samples, the sample can be excluded as originating from the same person or maternal lineage.

- Inclusion (failure to exclude): If the sequences are the same, the reference sample and evidence cannot be excluded as arising from the same source. When an mtDNA profile cannot be excluded, it is desirable to evaluate the weight of the evidence. In cases where the same heteroplasmy is observed in both questioned and known samples, its presence increases the strength of the evidence. However, if heteroplasmy is observed in a questioned sample, but not in a known sample or vice versa, a maternal lineage still cannot be excluded

- Inconclusive: If there is only one base difference between the questioned and known samples, one must consider this result inconclusive.

\section{Mitochondrial DNA databases}

There are two types of databases, national forensic DNA databases (restricted to a country and based on samples associated with a crime) and population DNA databases (random selection individuals representing a population) (Lembring, 2013). The following are different types of mtDNA population databases:

\section{FBI mtDNA database:}

The FBI has compiled the mtDNA population also known as CODIS mt for the purpose of being able to determine a legally defensible frequency estimate (Monson et al., 2002). The CODIS mt database has a forensic and a published literature component to it in order to separate data obtained from forensic laboratories and academic studies (Butler, 2011).

\section{EMPOP:}

The European forensic mtDNA sequencing community has been actively engaged for a number of years in developing new high-quality population database for forensic human identity testing applications, that can be accessed at http://www.empop.org (Parson and Dür, 2007). 
mtDNA manager:

A Korean group from Yonsei University has created an online mtDNA searchable population database called mtDNA manager and it can be accessed at http://mtmanager.yonsei.ac.kr/ (Lee et al., 2008).

\section{Conclusion}

Whereas forensic Anthropologists analyze human skeletal remains, to this purpose human mitochondrial DNA can be utilized as the best resource to identify the victim from skeletal remains, as we mentioned before, due to its especial features, the mtDNA offers several advantages over nDNA, it's high copy number, small size and circular form make it more resistant to degradation and more stable during long storage than nuclear DNA, due to which it is possible to analyze the mtDNA even in very small, damaged and degraded samples where nDNA is unavailable for the analysis, hence human mtDNA has enabled investigators such as forensic anthropologists to identify missing persons, war suffers and criminal cases. Of the whole genome, hypervariable regions (HVI, HVII, HVIII) of the non coding displacement region (D-loop) or control region (CR) in human mtDNA have proven to be a useful target for analysis of forensic materials, in which the amount of DNA is limited or highly degraded, polymorphisms hypervariable regions could provide evidence about the identity of crime victims, especially skeletal remains.

Conflicts of Interest: The authors declare no conflict of interest.

\section{References}

Adachi, N., Umetsu, K. and Shojo, H., 2014. Forensic strategy to ensure the quality of sequencing data of mitochondrial DNA in highly degraded samples. Legal Medicine, 16 (1), pp.52-55. 
Adams, B.J. and Byrd, J.E. eds., 2008. Recovery, analysis, and identification of commingled human remains. Springer Science \& Business Media.

Alaeddini, R., Walsh, S.J. and Abbas, A., 2010. Forensic implications of genetic analyses from degraded DNA—a review. Forensic science international: genetics, 4 (3), pp.148157.

Allard, M.W., Miller, K., Wilson, M., Monson, K. and Budowle, B., 2002. Characterization of the Caucasian haplogroups present in the SWGDAM forensic mtDNA dataset for 1771 human control region sequences. Journal of Forensic Science, 47 (6), pp.1215-1223.

Anderson, S., Bankier, A.T., Barrell, B.G., de Bruijn, M.H., Coulson, A.R., Drouin, J., Eperon, I.C., Nierlich, D.P., Roe, B.A., Sanger, F. and Schreier, P.H., 1981. Sequence and organization of the human mitochondrial genome. Nature, 290 (5806), p.457.

Andrews, R.M., Kubacka, I., Chinnery, P.F., Lightowlers, R.N., Turnbull, D.M. and Howell, N., 1999. Reanalysis and revision of the Cambridge reference sequence for human mitochondrial DNA. Nature genetics, 23 (2), p.147.

Amer, S.A., Al-Harthi, H.S., Refaat, A.M., Bakdash, A. and Kassab, A.C., 2017. Identification of Human Bone Remains by Autosomal STRs and Mitochondrial DNA SNPs. Journal of Hard Tissue Biology, 26 (2), pp.111-118.

Baasner, A., Schäfer, C., Junge, A. and Madea, B., 1998. Polymorphic sites in human mitochondrial DNA control region sequences: population data and maternal inheritance. Forensic science international, 98 (3), pp.169-178.

Ballantyne, J., 1997. Mass disaster genetics. Nature genetics, 15 (4), pp.329-331.

Bender, K., Schneider, P.M. and Rittner, C., 2000. Application of mtDNA sequence analysis in forensic casework for the identification of human remains. Forensic science international, 113 (1-3), pp.103-107.

Bini, C., Ceccardi, S., Luiselli, D., Ferri, G., Pelotti, S., Colalongo, C., Falconi, M. and Pappalardo, G., 2003. Different informativeness of the three hypervariable mitochondrial DNA regions in the population of Bologna (Italy). Forensic science international, 135 (1), pp.48-52. 
Blau, S., Catelli, L., Garrone, F., Hartman, D., Romanini, C., Romero, M. and Vullo, C., 2014. The contributions of anthropology and mitochondrial DNA analysis to the identification of the human skeletal remains of the Australian outlaw Edward 'Ned'Kelly. Forensic science international, 240, pp.e11-e21.

Bodner, M., Iuvaro, A., Strobl, C., Nagl, S., Huber, G., Pelotti, S., Pettener, D., Luiselli, D. and Parson, W., 2015. Helena, the hidden beauty: Resolving the most common West Eurasian mtDNA control region haplotype by massively parallel sequencing an Italian population sample. Forensic Science International: Genetics, 15, pp.21-26.

Bremer, J.R.A., Baker, A.J. and Mejuto, J., 1995. Mitochondrial DNA control region sequences indicate extensive mixing of swordfish (Xiphias gladius) populations in the Atlantic Ocean. Canadian Journal of Fisheries and Aquatic Sciences, 52 (8), pp.17201732.

Butler, J.M., 2011. Advanced topics in forensic DNA typing: methodology. Academic Press.

Calacal, G.C., Salvador, J.M., Sagum, M.S., Fortun, R.D. and De Ungria, M.C.A., 2018.

Pathology and DNA Analysis of Exhumed Human Remains Three-years Postmortem. Philippine Journal of Science, 147 (1), pp.9-16.

Divne, A.M., Nilsson, M., Calloway, C., Reynolds, R., Erlich, H. and Allen, M., 2005. Forensic casework analysis using the HVI/HVII mtDNA linear array assay. Journal of Forensic Science, 50 (3), pp.1-7.

Edson, S.M., Ross, J.P., Coble, M.D., Parson, T.J. and Barritt, S.M., 2004. Naming the dead-confronting the realities of the rapid identification of degraded skeletal remains. Forensic Science Review, 16 (1), pp.63-88.

Fridman, C. and Gonzalez, R.S., 2009. HVIII discrimination power to distinguish HVI and HVII common sequences. Forensic Science International: Genetics Supplement Series, 2 (1), pp.320-321.

Fujita, T., 1995. Identification of DNA polymorphism by asymmetric-PCR SSCP. Biotechniques, 19, pp.532-534.

Gabriel, M.N., Huffine, E.F., Ryan, J.H., Holland, M.M. and Parsons, T.J., 2001. Improved MtDNA sequence analysis of forensic remains using a "mini-primer set" amplification strategy. Journal of Forensic Science, 46 (2), pp.247-253. 
Gabriel, M.N., Calloway, C.D., Reynolds, R.L. and Primorac, D., 2003. Identification of human remains by immobilized sequence-specific oligonucleotide probe analysis of mtDNA hypervariable regions I and II. Croatian medical journal, 44 (3), pp.293-298.

Gomes, C., Fondevila, M., Palomo-Díez, S., Pardiñas, A.F., López-Matayoshi, C., BaezaRicher, C., López-Parra, A.M., Lareu, M.V., López, B. and Arroyo-Pardo, E., 2017. Phenotyping the ancient world: The physical appearance and ancestry of very degraded samples from a chalcolithic human remains. Forensic Science International: Genetics Supplement Series, 6, pp.e484-e486.

Hayat, S., Akhtar, T., Siddiqi, M. H. 2016. Human Mitochondrial DNA Characterization and Its Applications. European Journal of Pharmaceutical and Medical Research, 3 (11), 206-214.

Holland, M.M. and Parsons, T.J., 1999. Mitochondrial DNA Sequence AnalysisValidation and Use for Forensic Casework. Forensic science review, 11 (1), pp.21-50

Howell, N., Elson, J.L., Howell, C. and Turnbull, D.M., 2007. Relative rates of evolution in the coding and control regions of African mtDNAs. Molecular biology and evolution, 24 (10), pp.2213-2221.

Hughes-Stamm, S.R., 2012. DNA typing methods for highly degraded samples.

Imaizumi, K., Parsons, T.J., Yoshino, M. and Holland, M.M., 2002. A new database of mitochondrial DNA hypervariable regions I and II sequences from 162 Japanese individuals. International journal of legal medicine, 116 (2), pp.68-73.

Isenberg, A.R. and Moore, J.M., 1999. Mitochondrial DNA analysis at the FBI laboratory. Forensic Science Communications, 1 (2), pp.1-10.

Kaestle, F.A. and Horsburgh, K., 2002. Ancient DNA in anthropology: methods, applications, and ethics. American journal of physical anthropology, 119 (S35), pp.92-130.

Kinra, S.L.P., 2006. The use of mitochondrial DNA and short tandem repeat typing in the identification of air crash victims. Ind J Aerospace Med, 50 (1), p.55.

Kobilinsky, L. F., Levine, L., \& Margolis-Nunno, H. 2007. Forensic DNA analysis. Infobase Publishing. 
Köhnemann, S. and Pfeiffer, H., 2011. Application of mtDNA SNP analysis in forensic casework. Forensic Science International: Genetics, 5 (3), pp.216-221.

Kouvatsi, A., Karaiskou, N., Apostolidis, A. and Kirmizidis, G., 2001. Mitochondrial DNA sequence variation in Greeks. Human biology, pp.855-869.

Koyama, H., Iwasa, M., Maeno, Y., Kato, H., Tsuchimochi, T., Nakamura, Y.S., Ohtaki, J.M. and Nagao, M., 2008. Corrigendum to "Mitochondrial sequence haplotype in the Japanese population"[Forensic Sci. Int. 125 (2002) 93-96]. Forensic science international, 177 (2-3), pp.252-253.

Lander, N., Rojas, M.G., Chiurillo, M.A. and Ramírez, J.L., 2008. Haplotype diversity in human mitochondrial DNA hypervariable regions I-III in the city of Caracas (Venezuela). Forensic Science International: Genetics, 2 (4), pp.e61-e64.

Lee, S.D., Shin, C.H., Kim, K.B., Lee, Y.S. and Lee, J.B., 1997. Sequence variation of mitochondrial DNA control region in Koreans. Forensic science international, 87 (2), pp.99-116.

Lee, H.Y., Yoo, J.E., Park, M.J., Chung, U. and Shin, K.J., 2006. Mitochondrial DNA control region sequences in Koreans: identification of useful variable sites and phylogenetic analysis for mtDNA data quality control. International journal of legal medicine, 120 (1), pp.5-14.

Lee, H.Y., Song, I., Ha, E., Cho, S.B., Yang, W.I. and Shin, K.J., 2008. mtDNAmanager: a Web-based tool for the management and quality analysis of mitochondrial DNA controlregion sequences. BMC bioinformatics, 9 (1), p.483.

Lehocký, I., Baldovič, M., Kádaši, L. and Metspalu, E., 2008. A database of mitochondrial DNA hypervariable regions I and II sequences of individuals from Slovakia. Forensic Science International: Genetics, 2 (4), pp.e53-e59.

Lembring, M. 2013. Application of Mitochondrial DNA Analysis in Contemporary and Historical Samples (Doctoral dissertation, Acta Universitatis Upsaliensis).

Lincoln, P.J. and Thomson, J. eds., 1998. Forensic DNA profiling protocols (Vol. 98). Springer Science \& Business Media. 
Loreille, O.M., Diegoli, T.M., Irwin, J.A., Coble, M.D. and Parsons, T.J., 2007. High efficiency DNA extraction from bone by total demineralization. Forensic Science International: Genetics, 1 (2), pp.191-195.

Macaulay, V. and Richards, D.M., 2006. Human mitochondrial DNA and the evolution of Homo sapiens. Springer.

Maruyama, S., Minaguchi, K. and Saitou, N., 2003. Sequence polymorphisms of the mitochondrial DNA control region and phylogenetic analysis of mtDNA lineages in the Japanese population. International journal of legal medicine, 117 (4), pp.218-225.

Maruyama, S., Komuro, T., Izawa, H. and Tsutsumi, H., 2013. Analysis of human mitochondrial DNA polymorphisms in the Japanese population. Biochemical genetics, 51 (1-2), pp.33-70.

McAllister, P., Nagle, N. and Mitchell, R.J., 2013. The Australian Barrineans and their relationship to Southeast Asian Negritos: an investigation using mitochondrial genomics. Human biology, 85 (3), pp.485-502.

McBride, H.M., Neuspiel, M. and Wasiak, S., 2006. Mitochondria: more than just a powerhouse. Current biology, 16 (14), pp.R551-R560.

Melton, T., 2004. Mitochondrial DNA heteroplasmy. Forensic science review, 16 (1), pp. $1-20$

Mendisco, F., Keyser, C., Seldes, V., Nielsen, A.E., Russo, M.G., Crubézy, E. and Ludes, B., 2018. An insight into the burial practices of the late pre-Hispanic Los Amarillos community (northwestern Argentina) through the study of ancient DNA. Journal of Archaeological Science, 91, pp.12-19.

Monson, K.L.M., Miller, K.W., Wilson, M.R., DiZinno, J.A. and Budowle, B., 2002. The mtDNA population database: an integrated software and database resource for forensic comparison.

Pakendorf, B. and Stoneking, M., 2005. Mitochondrial DNA and human evolution. Annu. Rev. Genomics Hum. Genet., 6, pp.165-183.

Palo, J.U., Hedman, M., Söderholm, N. and Sajantila, A., 2007. Repatriation and identification of Finnish World War II soldiers. Croatian medical journal, 48(4), p.528. 
Parson, W. and Dür, A., 2007. EMPOP—a forensic mtDNA database. Forensic Science International: Genetics, 1(2), pp.88-92.

Ranasinghe, R., Tennekoon, K.H., Karunanayake, E.H., Lembring, M. and Allen, M., 2015. A study of genetic polymorphisms in mitochondrial DNA hypervariable regions I and II of the five major ethnic groups and Vedda population in Sri Lanka. Legal Medicine, 17 (6), pp.539-546.

Ricaut, F.X., Keyser-Tracqui, C., Bourgeois, J., Crubézy, E. and Ludes, B., 2004. Genetic analysis of a Scytho-Siberian skeleton and its implications for ancient Central Asian migrations. Human Biology, pp.109-125.

Rudbeck, L., Gilbert, M.T.P., Willerslev, E., Hansen, A.J., Lynnerup, N., Christensen, T. and Dissing, J., 2005. mtDNA analysis of human remains from an early Danish Christian cemetery. American journal of physical anthropology, 128 (2), pp.424-429.

Salas, A., Lareu, V., Calafell, F., Bertranpetit, J. and Carracedo, A., 2000. mtDNA hypervariable region II (HVII) sequences in human evolution studies. European Journal of Human Genetics, 8 (12), p.964.

Scientific Working Group on DNA Analysis, 2003. Guidelines for mitochondrial DNA (mtDNA) nucleotide sequence interpretation. Forensic Science Communications, 5 (2) Available at http://www2.fbi.gov/hq/lab/fsc/backissu/april2003/swgdammitodna.htm

Serin, A., Canan, H., Alper, B., Gulmen, M.K., Zimmermann, B. and Parson, W., 2016. Mitochondrial DNA control region haplotype and haplogroup diversity in South Eastern Turkey. Forensic Science International: Genetics, 24, pp.176-179.

Sheshanna, S. H., Hegde, U., Srinivasaiyer, M., \& Balaraj, B. M. 2014. Mitochondrial DNA: A Reliable Tool in Forensic Odontology. Journal of Indian Academy of Forensic Medicine, 36 (4), 407-410.

Shinoda, K.I., 2010. Mitochondrial DNA of human remains at Man Bac. Man Bac. The Excavation of a Neolithic Site in Northern Vietnam, 33, pp.95-116.

Slavec, Z.Z., 2012. New method of identifying family related skulls: forensic medicine, anthropology, epigenetics. Springer Science \& Business Media. 
Stenton, D., Keenleyside, A., Fratpietro, S. and Park, R., 2017. DNA analysis of human skeletal remains from the 1845 Franklin expedition. Journal of Archaeological Science: Reports, 16, pp.409-419.

Stoneking, M., Hedgecock, D., Higuchi, R.G., Vigilant, L. and Erlich, H.A., 1991. Population variation of human mtDNA control region sequences detected by enzymatic amplification and sequence-specific oligonucleotide probes. American journal of human genetics, 48 (2), p.370.

Tagliabracci, A., Turchi, C., Buscemi, L. and Sassaroli, C., 2001. Polymorphism of the mitochondrial DNA control region in Italians. International journal of legal medicine, 114 (4-5), pp.224-228

Thompson, T.J.U., 2003. Supply and demand: the shifting expectations of forensic anthropology in the United Kingdom. Science and Justice.

Torroni, A., Achilli, A., Macaulay, V., Richards, M. and Bandelt, H.J., 2006. Harvesting the fruit of the human mtDNA tree. TRENDS in Genetics, 22 (6), pp.339-345.

Wilson, M.R., Polanskey, D., Butler, J., DiZinno, J.A., Replogle, J. and Budowle, B., 1995. Extraction, PCR amplification and sequencing of mitochondrial DNA from human hair shafts. Biotechniques, 18, pp.662-669.

To cite this article:

Samehsalari S., Reddy K.R. 2018. Application control region of human mitochondrial DNA in forensic anthropology.

International Journal of Modern Anthropology. 2 (11): 233 - 248

DOI: http://dx.doi.org/10.4314/ijma.v2i11.11

\section{(i) $\Theta$}

This article, as all articles published in this journal, is under The Creative Commons Attribution: Attribution-NonCommercial-NoDerivatives 4.0 International (CC BY-NC-ND 4.0). https://creativecommons.org/licenses/by-nc-nd/4.0/ 